\title{
The immunochemical cross-reactivity between cytoplasmic and mitochondrial mammalian lysyl-tRNA synthetases
}

\author{
L. L. Sidorik, T. A. Rybkinska, N. G. Bakhiya, N. V. Rodnin, V. V. Filonenko, \\ N. S. Entelis ${ }^{1}$, I. A. Tarassov ${ }^{1}$, R. P. Martin ${ }^{1}$, G. Kh. Matsuka \\ Institute of Molecular Biology and Genetics National Academy of Sciences of Ukraine \\ Acad. Zabolotnoho vul., 150, Kyiv, 03143, Ukraine \\ ${ }^{1}$ UPR 9005, IBMC CNRS \\ Rue Rene Descart, 15, Strasbourg, France
}

\begin{abstract}
Animal and fungal cells (in contrast to prokaryotes) contain two distinct sets of related aminoacyl-tRNA synthetases (aaRSs) encoded by nuclear genes and functioning in cytosol and mitochondria. The structural differences between mitochondrial and cytoplasmic enzymes may reflect the functional adaptation to fulfil mitochondrial processes in addition to protein synthesis. Mitochondrial import of nuclear-encoded tRNAs has been described in yeast, plants and protozoans but it has not been observed in mammalian cells. It's established that mitochondrial lysyl-tRNA synthetase (MSK) plays a prominent role in the transport of tRNA into yeast mitochondria for complementation of mitochondrial tRNAs genes mutations. We tried to identify MSK homologues in mammalian cells with the help of monospecific antibodies against pre-MSK by ELISA and Western-blot analysis. We have identified cross-reactive proteins in mitochondrial and cytoplasmic fractions of mammalian cell lysates. These data, together with the results of crossaminoacylation on mitochondrial and cytoplasmic tRNAs, suggest the presence of common antigenic determinants in the mitochondrial and cytoplasmic lysyl-tRNA synthetases from higher animals.
\end{abstract}

Introduction. Aminoacyl-tRNA synthetases (aaRSs) (EC 6.1.1) - are a heterogeneous family of enzymes differing in size and subunit structure but catalyzing the same reaction of the selective attachment of amino acids to their cognate tRNAs. The animal and fungal cells (in contrast to prokaryotes) contain two different sets of related aaRSs encoded by nuclear genes, one set localized in the cytosol and functioning in the cytoplasmic protein synthesis while the second localized in mitochondria and functioning in the organella translation. In addition, plant cells posses the third set of aaRSs involved in the chloroplastic protein synthesis $[1,2]$.

The molecular and catalytic properties of cytoplasmic enzymes have been extensively studied over

(C) L. L. SIDORIK, T. A. RYBKINSKA, N. G. BAKHIYA

N. V. RODNIN, v. V. FILONENKO, N. S. ENTELIS,

i. A. TARASSOV, R. P. MARTIN, G. Kh. MATSUKA, 2000 the past 20 years. However, the information about mitochondrial aaRSs remained scarce so far. Studies of the organelle-specific synthetases are important for several reasons. The information about sequences of these enzymes contribute to better understanding of the evolution of this enzyme family. On the other hand, the structural differences between the mitochondrial and cytoplasmic enzymes reflect the functional adaptations to fulfil mitochondrial processes in addition to the protein synthesis. For example, in fungi, certain mitochondrial aaRSs are involved in either the splicing of mitochondrial RNAs [1, 2], or the import of tRNA from the cytoplasm [3].

In the yeast Saccharomyces cerevisiae, the selective import into mitochondria of one of the two cytoplasmic lysine isoacceptors, tRNA ${ }^{\text {Lys }} \mathrm{CUU}$, requires the integrity of the mitochondrial pre-protein import machinery as well as soluble cytosolic factors [4]. One of the essential import factors has been identified as the precursor of the mitochondrial lysyl- 
tRNA synthetase (pre-MSK). Furthermore, it has been shown that pre-MSK can selectively bind to the aminoacylated form of $\mathrm{tRNA}{ }^{\text {Lys }} \mathrm{CUU}$ (and to importable mutant tRNAs) and is, therefore, likely to act as a carrier for transport of the tRNA across the mitochondrial membrane [5].

The mitochondrial import of nuclear-coded tRNAs appears to be a widely spread process among eukaryotes since it has been described not only in yeast but also in plants and protozoans [6, 7]. However, this process is likely not to occur in mammalian cells. Establishing artificial system of tRNA mitochondrial import in human cells could be of high biomedical interest because several human mitochondrial neurodegenerative and muscular diseases (such as MERRF and MELAS syndromes and several cardiomyopathies) are associated with point mutations in mitochondrial tRNA genes [8]. Indeed, theoretically such defects should be cured by expressing functional tRNAs in the nucleus and imporling them from the cytoplasm to mitochondria.

Because the mitochondrial lysyl-tRNA synthetase plays a prominent role in the transport of tRNA into yeast mitochondria, we tried to identify MSK homologues in mammalian cells with the help of monospecific polyclonal antibodies directed against the yeast pre-MSK by ELISA and Western-blot analysis. We have identified cross-reactive proteins in mitochondrial and cytoplasmic fractions of mammalian cells lysates possessing an electrophoretic mobility similar to that of yeast pre-MSK. These data, together with the results of cross-aminoacylation studies on mitochondrial and cytoplasmic tRNAs, suggest the presence of common antigenic determinants in mitochondrial (mt) and cytoplasmic (ct) lysyl-tRNA synthetases (LysRSs) from the mammals and allow us to suppose that mammalian mitochondrial and cytoplasmic lysyl-tRNA synthetases could be encoded by the same gene.

Materials and Methods. Protein G-Sepharose was from «Sigma-Aldrich» (USA); anti-rabbit IgG labelled by horse-radish peroxidase from «DAKO» (Denmark); unfractionated yeast cytoplasmic and Escherichia coli tRNAs were from «Boehringer-Mannheim» (Germany); the immunoblotting detection ECL system and $\left[{ }^{14} \mathrm{C}\right]$-Lys from «Amersham» (USA); all other chemicals were from «Merck» (Germany), «Sigma» (USA) and «Bio-Rad» (USA).

The high molecular weight complex of cytoplasmic aaRSs was purified from bovine and rabbit liver by the immunoprecipitation method on the affinity column with coupled monoclonal antibodies against rabbit cytoplasmic GluRS accordingly to the described method [9].
Recombinant pre-MSK was obtained using the Pichya pastoris expression system («Invitrogen») and purified on DEAE-cellulose and Mono-Q Sepharose.

Isolation of mammalian mitochondria and preparation of a mitochondrial crude extract. Mitochondria from rabbit liver were obtained as described in [10] with some modifications. Rabbit liver was briefly homogenized in buffer A: $25 \mathrm{mM}$ Tris/ $\mathrm{HCl}, \mathrm{pH} 7.5$, $2 \mathrm{mM}$ EDTA, $1.5 \mathrm{mM} \mathrm{CaCl}_{2}, 250 \mathrm{mM}$ sucrose. Nuclei and cell debris were removed by two $5 \mathrm{~min}$ sequential centrifugation at low speed (1000 x $g$ for $5 \mathrm{~min})$ and mitochondria were collected by high-speed centrifugation $(10000 \times \mathrm{g}$ for $10 \mathrm{~min})$ and washed three times with $250 \mathrm{mM}$ sucrose in TE buffer $(25 \mathrm{mM}$ Tris/ $\mathrm{HCl}$, pH 7.5, $2 \mathrm{mM}$ EDTA). The mitochondrial fraction in $250 \mathrm{mM}$ sucrose and TE was layered on a sucrose step-gradient consisting $50 \%, 36 \%$ and $20 \%$ sucrose in buffer B $(50 \mathrm{mM}$ Tris $/ \mathrm{HCl}, \mathrm{pH} 7.5$, $2 \mathrm{mM}$ EDTA, $1 \mathrm{~g} / 1$ bovine serum albumin) and centrifuged at $25000 \mathrm{rpm}$ (1 h, rotor Beckman SW27). Intact mitochondria collected from the $36 \%$ sucrose layer were diluted in 4 volumes $0.5 \mathrm{M}$ sorbitol and centrifuged at $22000 \times \mathrm{g}$ for $15 \mathrm{~min}$.

To obtain a mitochondrial crude extract, pelleted mitochondria were suspended in buffer $\mathrm{C}$ ( $25 \mathrm{mM}$ potassium phosphate, $\mathrm{pH} 7.5,10 \mathrm{mM} \mathrm{MgCl}, 1 \mathrm{mM}$ EDTA, I mM phenylmethylsulfonyl fluoride, $10 \%$ glycerol) and disrupted by sonication. Membranous debris were removed by centrifugation at $10000 \times g$, $50 \mathrm{~min}$.

Protein concentration was estimated by the Bradford method [11].

Mitochondrial tRNA was purified from bovine liver mitochondria according to the method [12].

Preparation of antibodies against pre-MSK. The partially purified protein $(50 \mu \mathrm{g})$ was electrophorized in $12 \%$ PAAG-SDS gel [13] and transferred onto a nitrocellulose filter. The colored band with apparent molecular weight consistent with that of pre-MSK was cut, dissolved in DMSO and used for immunization. Rabbit was immunized by $30-40 \mu \mathrm{g}$ of pre-MSK extracted in DMSO with complete Freund's adjuvant $(1: 1, v / v)$. A booster of $30 \mu \mathrm{g}$ of antigen in incomplete Freund's adjuvant was administered twice at 3 weeks intervals. The serum was collected, and immunoglobulins were precipitated with ammonium sulfate buffer at $50 \%$ of saturation, and then purified by three chromatographic steps on DEAE-cellulose, on Protein G-Sepharose (according to the Firm protocol) and on an affinity column with coupled antigen [14] to obtain high-affinity and specific anti-pre-MSK antibodies.

The specificity of antibodies fractions obtained at each purification step was controlled by the ELISA 
THE CROSS-REACTIVITY BETWEEN LYSYL-TRNA SYNTHETASES

method and their purity was estimated by $12 \%$ PAGE-SDS electrophoresis.

Western-blot analysis. Lysates (cytoplasmic and mitochondrial) of cells and organs were electrophorized in $12 \%$ PAAG-SDS gel and transferred onto a nitrocellulose membrane. Washing and blockage of the membrane was done in TBS-T-M buffer (TBS buffer with $0.1 \%$ Tween-20 and $5 \%$ dry milk) during at $1 \mathrm{~h}$ at $25{ }^{\circ} \mathrm{C}$. Incubation with antibodies in TBS-T-M was during $2 \mathrm{~h}$ at $25^{\circ} \mathrm{C}$. After extensive washing with TBS-T-M, the filters were incubated with anti-rabbit IgG labelled by peroxidase in TBST-M during $2 \mathrm{~h}$ at $25^{\circ} \mathrm{C}$. After extensive washing with TBS-T, the fluorogene ECL was added to the filters (according to the firm protocol) and after 10 min of incubation filters were autographied on an $\mathrm{X}$-ray film («Kodak») for visualization of the signals.

Aminoacylation assay. Lysyl-tRNA synthetase aminoacylation test was performed in $0.1 \mathrm{ml}$ of the mixture containing $100 \mathrm{mM}$ Tris/ $\mathrm{HCl}, \mathrm{pH} 7.5$, $30 \mathrm{mM} \mathrm{KCl}, 10 \mathrm{mM} \mathrm{MgCl}_{2}, 2 \mathrm{mM}$ ATP, $60 \mu \mathrm{M}$ $\left[^{3} \mathrm{H}\right]$-Lysine $(60-80 \mathrm{Ci} / \mathrm{mmol}$, «Amersham»), with saturating amounts of relevant unfractionated tRNA and limiting amounts of enzyme. A unit of activity corresponds to $1 \mathrm{nmol}$ aminoacyl-tRNA formed at $37^{\circ} \mathrm{C}$.

The influence of antibodies on the aminoacylating activity of the mitochondrial and cytoplasmic Iysyl-tRNA synthetases was detected according to the method [14].

Results and Discussion. A problem of obtaining antibodies of high specificity and affinity is connected with the homogeneity of antigen, the scheme of immunization and the methods of antibodies purification. The purification of majority of recombinant antigens is problematic without use of specific affine ligands. In our case the absence of such a ligand for the antigen (pre-MSK), low level of the recombinant protein secretion by producent and disability to purify the antigen to homogeneity put forward a problem of working out an effective method of immunization and following antibodies purification to produce antibodies of high titer and specificity.

Our scheme of immunization allowed us to obtain the antisera with titer more than 1:10000. The affinity of antibodies increased after each purification stage accompanied by simultaneous nonspecificity decreasing. Fig. 1 and Fig. $2(A, B)$ represent the immunoreactivity of the antibodies after different stages of purification. It is obvious that even after protein G-Sepharose chromatography (Fig. 1) the affinity of antibodies is not enough for the antigen detection in cell and tissue lysates. Only after their purification on the affine column with coupled antigen

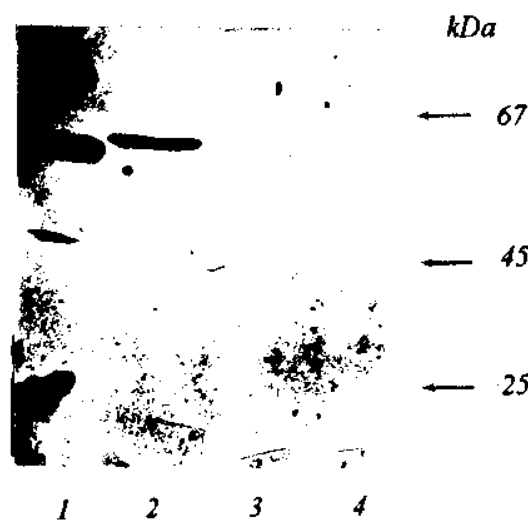

Fig. 1. Immunoreactivity of anti-pre-MSK antibodies after purification on DEAE-cellulose and Protein G-Sepharose columns, determined by Western-blot analysis: I - yeast pre-MSK; 2 ctlysRS (high molecular weight complex from bovine liver); 3 lysate of mitochondria from bovine liver; 4 - post-mitochondrial supernatant (S100) from bovine liver; The position of protein molecular weight standard indicated by arrows
$A$

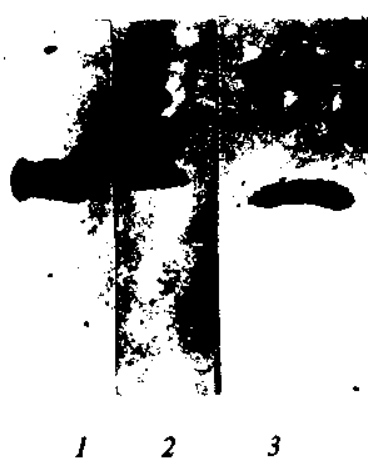

$B$

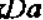

Fig. 2. Immunoreactivity of monospecific anti-pre-MSK antibodies (after immune-affine purification) determined by Western-blot analysis: (A) 1 -lysate of mitochondria from rabbit liver; 2 postmitochondrial supernatant $(\mathbf{S 1 0 0 )}$ of rabbit liver; 3 -yeast pre-MSK; ( $B$ ) $I$ - lysate of mitochondria from human placenta; 2 - posmitochondrial supernatant (S1OO) from human placenta

(pre-MSK) the affinity was considered satisfactory (Fig. 2),

The studies of antibodies immunoreactivity with cell and tissue lysates have shown that mentioned antibodies recognized the polypeptide band with electrophoretic mobility corresponding to that of LysRS subunit in the majority of the lysates investigated 


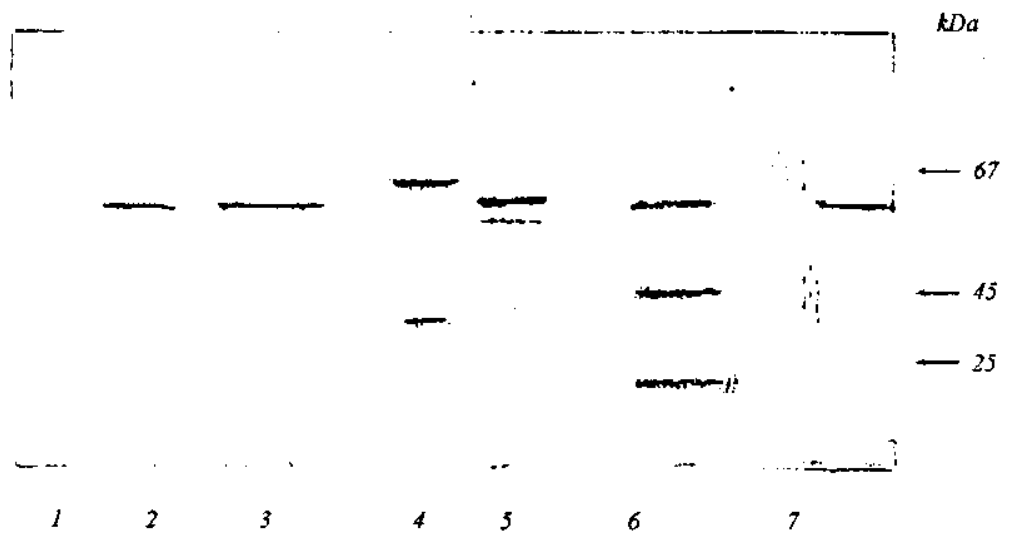

Fig. 3. Immunoreactivity of monospecific anti-pre-MSK antibodies detected by Western-blot analysis in mitochondrial and cytoplasmic (S100) lysates from different cells and mammalian organs: $I-$ bovine serum albumin (control of non-specificity); $2-$ high molecular weight complex from bovine liver; 3 - mitochondrial lysate from bovine liver; 4-cytoplasmic lysate (S100) from rabbit liver; 5 - lysate of yeast mitochondria; 6- cytoplasmic (S100) lysate of yeast; 7 - pre-MSK
(Fig. 3). The occurence of several low molecular weight peptides in yeast lysate (Fig. 3, lane 6) is a result of high level of endogeneous proteolysis in yeast.

The study of he antibodies influence on the enzymatic activity of mammalian mtLysRS and ctLysRS in the reaction of aminoacylation did not demonstrate any effect on this activity. One could suggest that anti-pre-MSK monospecific antibodies were directed against non-catalytic domains of both enzymes investigated (data not shown).

The data of the cross-aminoacylation experiments (Fig. 4) have shown unusual properties of the mammalian mitochondrial LysRS - a high level of aminoacylation of the cytoplasmic tRNA by the mitochondrial enzyme comparing with that for the mitochondrial tRNAs. We have found that mtLysRS aminoacylated the cytoplasmic tRNAs with the same efficiency as LysRS from cytoplasmic high molecular weight complex (ctLysRS). On the other hand, mtLysRS aminoacylated the mitochondrial tRNAs but did not aminoacylate $E$. coli tRNAs in fact. In contrast yeast mtLysRS is known to aminoacylate $E$. coli tRNA with the same efficiency as yeast mitochondrial tRNA but practically is not able to aminoacylate the cytoplasmic tRNA from yeast [15]. The data published recently about expression and characterization of the human mitochondrial PheRS [16] and LeuRS [17] have shown that these enzymes expressed in functionally active monomeric form are able to aminoacylate $E$. coli tRNA but less effectively than the yeast cytoplasmic aaRSs. Whether the dis- tinct properties of mtLysRSs from higher eukaryotes revealed are specific or common features of other mammalian mitochondrial aaRSs - is to be elucidated.

Most eukaryotic cells possess at least two compartmentally distinct sets of aaRSs, one located in the cytoplasm, and the other - in mitochondria (plants have the third set of chloroplast-specific synthetases). In some instances the same gene can code for both the mitochondrial and cytoplasmic aaRSs [18, 19]. More commonly, however, the functionally equivalent homologues are encoded by different genes. This is the case for the two lysyl-tRNA synthetases (KRS and MSK) of yeast. The gene KRS1, described by Mirande and Waller [20], has been shown to code for the cytoplasmic LysRS. The MSK1 gene, reported by Gatti and Tsagoloff [15], codes for the homologous yeast mitochondrial synthetase. However, concerning the LysRSs from higher eukaryotes, our knowledge is restricted to the information on the cytoplasmic synthetases functioning in the high molecular weight complex.

Based on the theory of Wong [21] that the genetic code may have evolved «hand-in-hand» with biosynthetic pathways for new amino acids and the hypothesis about mitochondria as prokaryotic endosymbiont incorporated into ancient eukaryotic cells [22-25], our data on the immunochemical crossreactivity between the cytoplasmic and mitochondrial mammalian lysyl-tRNA synthetases taken together with those on the cross-aminoacylation (Fig. 4) allow us to suppose that the mitochondrial and cytoplasmic 


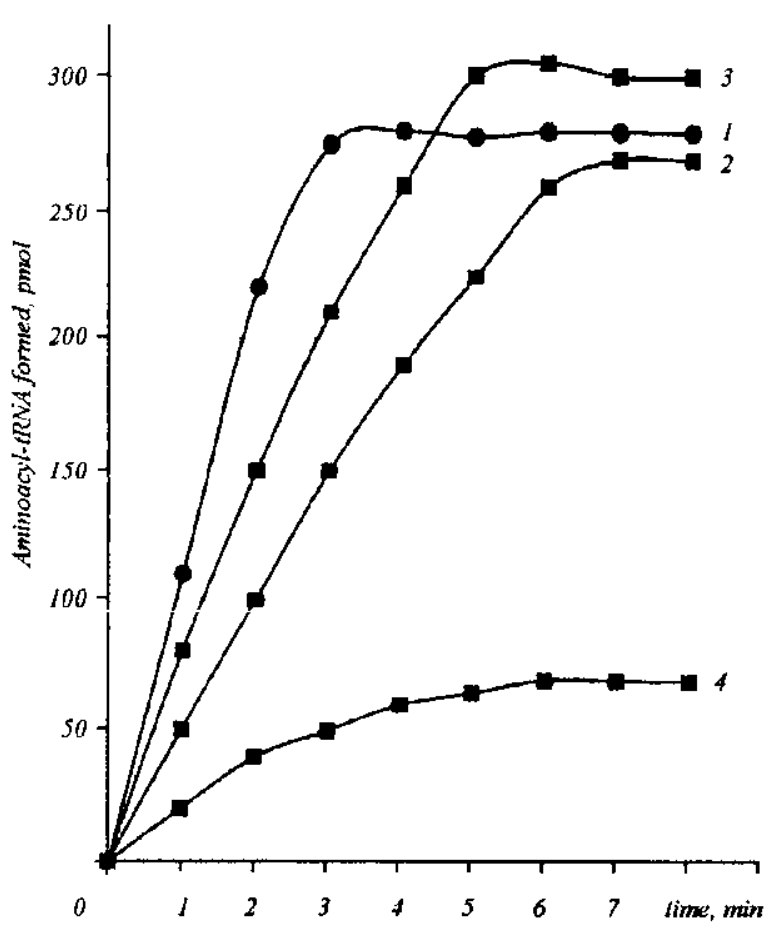

Fig. 4. Aminoacylation of tRNA by cytoplasmic LysRS (o) and mitochondrial LysRS (o): The time courses of aminoacylation of cytoplasmic tRNA by LysRS from high molecular weight complex of rabbit liver ( $I$ ) and LysRS from rabbit mitochondria (2); of mitochondrial tRNA (3) and E. coli tRNA (4) by LysRS from rabbit mitochondria

lysyl-tRNA synthetases of mammals could be encoded by the same gene. Our suggestion has been approved by recently published data concerning the unusual alternative splicing of the human lysyl-tRNA synthetase gene which encodes for both the cytoplasmic and mitochondrial enzymes [26].

Further investigation of the mammalian mitochondrial LysRS is important not only for solving many questions in the protein biosynthesis, molecular import into organelles, molecular evolution of aaRSs, but has a practical value as many severe pathologies are connected with mitochondrial disfunctions, especially with mutations in tRNA ${ }^{\text {Lys }}$ gene and defects in the protein importing machine, with a leading role of KRS and preMSK. 1515 .
Л. Л. Сидорик, Т. О. Рибкінська, Н. Г. Бахія, М. В. Роднін, В. В. Філоненко, Н. С. Ентеліс, Л. О. Тарасов, Р. П. Мартан, Г. Х. Мацука

Перехресна імунореактивність між цитоплазматичними і мітохондріальними лізил-тPНК синтетазами ссавців

Резюме

Клітини еукаріот на відміну від прокаріот містять дві різні групи аміноацил-тРНК синтетаз, які кодуються ядерним геномом та функціонують в цитозолі і мітохондріях. Структурні відмінності між ферментами мітохондрій $і$ цитоплаз ми мохуть бути відображенням функціональної адаптації до процесів, які відбуваються в мітохондріях, крім участі в біосинтезі білка. Iмпорт цитозольних тРНК у мітохондрї описано для дріжджів, рослин $і$ найпростіших, однак він не спостеріzався в клітинах ссавців. Виявлено, цо мітохондріальна лізил-тРНК синтетаза (MSK) відіграс провідну роль у транспорті тPHК у мітохондрії дріжджів для комплементації мутацій мітохондріальних генів тРНК. За допомогою моноспецифічних антитіл проти пре-MSK ми зробили спробу ідентифікувати гомологи MSK у клітинах ссавців методами ELISA $i$ Вестерн-блотинга. $B$ цитоплазматичних $i$ мітохондріальних фракціях лізатів клітин ссавців нам вдалося виявити білки, які мають імунологічний перехрест з MSK. Разом з результатами перехресного аміноацилювання ці дані дають підставу для припущення щодо наявності спільних антигенних детермінант у мітохондріальних і цитоплазматииних лізил-тРНК синтетаз ссавців.

Л. Л. Сидорик, Т. А. Рибкинска, Н. Г. Бахия, Н. В. Роднин, В. В. Филоненко, Н. С. Энтелис, И. А. Тарасов, Р. П. Мартан, Г. Х. Мацука

Перекрестная иммунореактивность между цитоплазматическими и митохондриальными лизил-тРНК синтетазами животных

\section{Резюме}

Клетки эукариот (в отличие от клеток прокариот) содержат две различные группы аминоацил-тРНК синтетаз, кодируе мых ядерным геномом и функционируюиих в цитозоле и митохондриях. Структурные отличия мехду ферментами митохондрий и читоплазмы могут быть отрахением функциональной адаптации к процессам, происходящим в митохондриях помимо уиастия в биосинтезе белка. Импорт цитозольных тРнК в митохондрии описан у дрожжей, растений и простейиих, однако не наблюдался в клетках млекопитаюцих. Установлено, что митохондриальная лизил-тРНК синтетаза (MSK) играет ведуцую роль в транспорте тPHК в митохондрии дрожжей для комплементации мутаций митохондриальных генов тРНК. С помощью моноспецифических антител против пре-MSK мы попьтались идентифицировать гомологи MSK в клетках млекопитающих методами ELISA и Вестерн-блотинга. В читоплазматических и митохондриальных фракциях лизатов клеток млекопитающих нам удалось обнарухить белки, имеющие иммунологический перекрест с MSK В совокупности с результатами перекрестного аминоа цилирования эти даннье дают основание предположить наличие обиих антигенных детерминант у митохондриальных и цитоплазматических лизил-тРНК синтетаз высиих живоmныx.

\section{REFERENCES}

1. Akins R. S., Lambowitz A. M. A Protein required for splicing group I introns in Neurospora mitochondria is mitochondrial 
tyrosyl-tRNA synthetase or a derivative thereof // Cell.1987.-50, N 1.-P. 331-345.

2. Labouesse J., Herbert C. J., Dujardin G., Slominski P. P. Three suppressor mutations which cure a mitochondrial RNA maturase deficiency occur at the same codon in the open reading frame of the nuclear NAM2 gene // EMBO J.1987.-6, N 2.-P. 713-721.

3. Entelis N. S., Krasheninnikov 1. A., Martin R. P., Tarassov J. A. Mitochondrial import of a yeast cytoplasmic tRNALys: possible roles of aminoacylation and modified nucleosides in subcellular partitioning // FEBS Lett.-1996.-384.-P. 3842.

4. Tarassov I., Entelis N., Martin R. P. An Intact protein translocating machinery is required for mitochondrial import of a yeast cytoplasmic tRNA // J. Mol. Biol.-1995.-245.-P. 315-328.

5. Entelis N. S., Kieffer S., Kolesnikova O. A., Martin R. P. Tarassov I. A. Structural requiremets of tRNA ${ }^{\text {Lys }}$ for its import into yeast mitochondriaad // Proc. Nat. Acad. Sci. USA.1998 -95, N 6.-P. 2838-2843.

6. Dietrich A., Weil J. H., Marechal-Drouard $L$ Nuclear-encoded transfer RNAs in plant mitochondria // Annu. Rev. Cell Biol.-1992.-8.-P. 115-131.

7. Schneider A., Martin J., Agabian N. A nuclear encoded tRNA of Trypanosoma brucei is imported into mitochondria // Mol. Cell. Biol. $-1994 .-14 .-P$. $2317-2322$.

8. Luft $R$. The development of mitochondrial medicine // Proc. Nat. Acad. Sci. USA. - 1994.-91.-P. 8731-8738.

9. Filonenko V. V., Deutcher $M$. Evidenve for similar structural organization of the multienzyme aminoacyl-tRNA synthetase complex in vivo and in vitro // J. Biol. Chem.-1994.-269.P. 17375-17378.

10. Ausenda C., Chromyn A. Purification of mitochondrial DNA from human cell cultures and placenta // Meth. Enzymol.1996.-264.-P. 122-128.

11. Bradford M. M. A rapid and sensitive method for quantitation of microgram quantities of protein utilizing the principle of dye binding // Anal. Biochem.-1976.-72.-P. 248-254.

12. Brungraber $E$. $A$. A simplified procedure for the preparation of *soluble RNA from rat liver // Biochem. Biophys. Res. communs. $-1962 .-8 .-$ P. $1-3$.

13. Laemmli $U$. $K$ Cleavage of structural proteins during in the assembly of the bacteriophage T4 // Nature.-1970.-227, N 5.-P. $680-685$.
14. Sidorik L. L., Gudzera O. I., Dragovoz V. A., Tukalo M. A., Beresten $S$. $F$. Immuno-chemical non-cross-reactivity between eukaryotic and prokaryotic seryl-tRNA synthetases // FEBS Lett. -1991.-292, N 1, 2.-P. 76-78.

15. Gatti $D . L, T$ sagoloff $A$. Structure and evolution of a group of related aminoacyl-tRNA synthetases // J. Mol. Biol.-1991.218. -P. 557-568.

16. Bullard J. M., Cai Y.-C., Demeler B., Spremulli $L$ L $L$ Expression and characterization of a human mitochondrial phenylalanyl-tRNA synthetase // J. Mol. Biol.-1999.288.-P. 567-577.

17. Bullard J. M., Cay Y. C., Spremulli $L$. L. Expression and characterization of the human mitochondrial leucyl-tRNA synthetase // Biochim. et biophys. acta. $-2000 .-1490$, N 3.-P. $245-258$.

18. Tzagoloff A., Gatti D., Gampel A. Mitochondrial aminoacyltRNA synthetases // Progr. Nucl. Acid Res. Mol. Biol.1990.-39.-P. 129-158.

19. Natsoulis G., Higler F., Fink G. R. The HTS1 gene encodes both the cytoplasmic and mitnchnndrial histidine tRNA synthetases of $S$. cerevisiae // Cell.-1986.-46.-P. 235-243.

20. Mirande M., Waller J.-P. The yeast lysyl-tRNA synthetase gene // J. Biol. Chem.-1988.-263.-P. 18433-18451.

21. Wong J. T.-F. Role of minimization of chemical distances between amino acids in the evolution of the genetic code // Proc. Nat. Acad. Sci. USA.-1980.-77.-P. 1083-1086.

22. Schwartz R. M., Dayhoff $M$. O., Schwartz R. M., Dayhoff $M$. Origins of prokaryotes, eukaryotes, mitochondria and chloroplasts // Science. - 1978.-199.-P. 395-403.

23. Borst P., Grivell $L A$. The mitochondrial genome of yeast // Cell.-1978.-15.-P. 705-723.

24. Nagel G. M., Doolittle R. F. Evolution and relatedness in two aminoacyl-tRNA synthetase families // Proc. Nat. Acad. Sci. USA.-1991.-88.-P. $8121-8125$.

25. Lipman R. S. A., Hou Y.-M. Aminoacylation of tRNA in the evolution of an aminoacyl-tRNA synthetase // Proc. Nat. Acad. Sci. USA - 1998. -95.-P. 13495-13500.

26. Tolkunova E., Park H., Xia J., King M. P., Davidson E. The human lysyl-tRNA synthetase gene encodes both the cytoplasmic and mitochondrial enzymes by means of an unusual alternative splicing of the primary transcript // J. Biol. Chem.-2000, August 21 (preprint).

УдК 577.1

Received 10.06.99 